\title{
SOCIAL STORIES AND DIGITAL LITERACY PRACTICES FOR INCLUSIVE EDUCATION
}

\author{
Asimina Riga ${ }^{1 i}$, \\ Vasiliki Ioannidi ${ }^{1}$, \\ Nikolaos Papayiannis ${ }^{2}$ \\ ${ }^{1}$ Hellenic Open University, \\ Greece \\ ${ }^{2} \mathrm{MA}$ in American Literature, \\ Aristotle University of Thessaloniki, \\ Greece
}

\begin{abstract}
:
This article deals with current issues of modern pedagogical practices incorporated in Special and Inclusive Education and touches upon Social Stories as a supplementary powerful learning tool especially in cases of children with autism and other similar communication deficits. According to our literature review, Social Stories better respond to the needs and abilities of the children personality regardless of their age by presenting a considerable amount of social information and best describing social schemata and situations. Also, they provide guidance for socially appropriate attitudes and behaviors, encouragement and support in learning and educational setting, both verbally and visually supported. To set the theoretical frame of this topic, an overview of social constructivism theory and the Unified Theory of Acceptance and Use of Technology are provided. Moreover, what is also under discussion in this article relates to the new digital challenges that have lately emerged after the combination of Social Stories with ICTs.
\end{abstract}

Keywords: social stories, inclusive learning, information technology, digital challenges

\section{Introduction}

The definitions of "inclusion" and "inclusive education" have shifted from a limited focus on disability per se and have gained a broader meaning, referring specifically to students who are often at risk of educational and social exclusion. "Education without exclusions" means establishing such a framework that all children included in it, regardless of their ability, gender, language, national or cultural origin - can be equally valued, treated with respect and provided with an equivalent number of authentic learning opportunities

'Correspondence: email riga.asimina@ac.eap.gr, mina riga@yahoo.gr 
(Mittler, 2000; Evans \& Lunt, 2002). Such a view related to inclusion is a real challenge for existing educational structures and modern social systems (Booth, 1996).

However, in the field of education, inclusion involves the process of reforming and restructuring the broader concept of school institution as a whole, ensuring by all means that, eventually, every single student is going to have access to the full range of educational and social opportunities delivered by every school unit. This refers to the established curriculum, the evaluation process, the recording and reporting of students' assignments and achievements, the decisions made about grouping students to schools or classrooms, pedagogical and teaching practices followed within classrooms, as well as leisure time and entertainment opportunities (Mittler, 2000). Consequently, "Inclusive education" nowadays calls for a radical change in deeply rooted educational mentalities requesting from the school staff to willingly renounce their practices in terms of student grouping, assessment and teaching and to adopt up to date techniques during their teaching (Ioannidi, 2020).

In this sense, individual differences are addressed as a normal and expected reality within the whole spectrum of education while the learning process tends to adjust each student's needs. This is the reason why particularly students with Special Educational Needs must have access to mainstream school curricula which must meet their individual needs by both designing and implementing appropriate student-centered teaching methods, from which ultimately all students benefit equally (Efstathiou, 2015).

Well trained and efficient teachers decide to incorporate special instructional tools in an attempt to modify their teaching methodology so as to cater for the special needs of all their students. To accomplish that, they take advantage of current pedagogical methods as it has been proven that they provoke and sustain students' interest, boost their performance and ameliorate their behavior (Riga, 2018). These methods mainly concern teaching tools that engage more of the students' senses throughout the learning task and hence them to enrich that process and redefine their methodological approaches. Such a teaching tool is best described with the term "Social Stories".

Social Stories have always been a widespread tool in the teaching procedure since their original appearance. It can mainly be used in students with Autism Spectrum Disorder (ASD), teaching them specific competences so that they can behave accordingly within the social rule contexts. Lately, Social Stories have been used both in cases of students with ASD and of those children showing undesired conduct such as inappropriate actions and reactions (Leach \& Duffy, 2009).

In general, these stories are based on a social background which presupposes that communication is a two-way process and, as a result, any sign of social malfunction is a problematic figure shared not only by students with autism but by the interlocutor, as well. Apparently, Social Stories stand for a teaching tool, an educational practice, labeled as an intervention technique in Inclusive Education between a practitioner and / or a parent etc. Both sides intend on the one hand to examine the autistic person's educational evolution facing adaptation and behavior problems along with communication and other learning impairments whereas on the other hand to communicate with him/her in an 
attempt to exchange and mutually share social concepts and relevant information (http://best-practice.middletownautism.com/approaches-of-intervention/social-stories/). This article deals with current issues of modern pedagogical practices incorporated in Special and Inclusive Education and touches upon Social Stories as a supplementary powerful learning tool especially in cases of children with autism and other similar communication impairments. To set the theoretical frame of this topic, an overview of social constructivism theory is provided. Moreover, what is also under thorough discussion in this paper relates to the new digital challenges that have lately emerged after the combination of Social Stories with ICTs.

\section{Theoretical Framework}

Indeed, there are many scientifically established debates as well as broad discussions concerning theories related to Social Stories (Bawazir \& Jones, 2017). This paper, in particular, suggests that Social Stories rely basically on Social Constructivism theory given that the latter offers more insight into the theoretical underpinnings of these stories. In fact, Social Constructivism emphasizes the collaborative nature of learning on the one hand while, on the other, it supports the acquisition of knowledge by a social group through interaction (McLeod, 2019).

Collaborative learning is defined as "a process by which students interact in pairs or small groups of no more than six members with intent to solicit and respect the abilities and contributions of individual members" (Udvari-Solner, 2012). Recent studies in digital storytelling have increasingly integrated learner collaboration into their project design (Alameen, 2011; Lee, 2014; Robin, 2016; Sadik, 2008; Smeda, Dakich \& Sharda, 2014; Standley, 2003) contrary to earlier studies in which the project was typically designed as an individual learning activity (Tsou, Wnag, \& Tzeng, 2006; Verdugo \& Belmonte, 2007). For example, Nishioka (2016) implemented digital storytelling as a collaborative learning tool in the language classroom providing learners with the opportunity to discuss language problems with their peers and co-construct knowledge of their target language. Indeed, the findings showed that collaborative digital storytelling project helped students to learn the target language in the project. Indeed, a number of story development models have been created in recent years to help educators achieve better outcomes with digital storytelling by creating an innovative e-Learning system based on Web 2.0 tools, a constructivist learning environment for knowledge remixing, sharing, and reusing through digital storytelling (Smeda, Dakich, and Sharda, 2012).

Additionally, digital storytelling encompasses interactivity (Park \& Seo, 2009; Gregori-Signes, 2014) which refers to the participation of users in the development of the stories using media characteristics that can be mutually exchanged. Learners can easily share their stories with a large audience as well as interact with them either by uploading their stories on Web 2.0 platforms or producing digital stories using Web 2.0 applications. For example, Alameen (2011) and Lee (2014) exploited the interactivity of Web 2.0 digital storytelling applications to promote learner collaboration by requiring learners to provide feedback to their classmate using their interactive functions. Furthermore, digital 
storytelling can develop the four core language skills (i.e., speaking, listening, writing, and reading) as well as to discuss language problems with peers, communicate using target language in meaning contexts, and share their final work product with an authentic audience for authentic communication purposes (Lee, 2014; Nishioka, 2014).

Students with Special Educational Needs always lack in flexibility regarding their thinking and thus they manifest a way of thinking within the confines of a particular concept they are familiar with. As is usually the case, Social Stories create context for meaningful communicative interaction between teacher and students or among students (Bawazir \& Jones, 2017). In case of students with ASD, Social Stories have also been created in such a way that students can more easily process the information being provided with, supported by either their parents or their teacher-therapist. At the same time according to Sansoti \& Powell-Smith (2008), children with ASD find electronics, including computers intrinsically motivating (especially males) and, therefore, become more engaged in the skill being acquired. Social learning theory eloquently explains the role of observational learning in both modeling and developing different social behaviors and has equally demonstrated that people can gain meaningful social information when observing others, including mass media representations (Bandura, 2001).

\section{Unified Theory of Acceptance and Use of Technology (UTAUT)}

It has been argued among prior and contemporary researches that creating a social story through digital media arouses children's interest and reinforces their creativity, becoming thus more preoccupied with a subject matter being taught (Meadows, 2003; O'Byrne, Stone, \& White, 2018; Robin, 2006; Sadic, 2008; Yuksel et al., 2011). Intriguingly, Kennedy et al. (2019) have investigated that engaging the participants in making up their own Social Stories is far more effective than just passively viewing existing ones. Students can enhance both their general knowledge and academic skills as they are firstly asked to do some meticulous research on a specific topic, then look for relevant pictures, record their voice and eventually end up with a particular point of view. Compared to conventional storytelling, digital storytelling indisputably provides a multimedia representation of an experience, which, in turn, extends the modal choices available by learners during the process of story shaping. All this highly productive learning procedure is technically aided by their capturing the users' sounds, texts and pictures and also by allowing a seamless combination of modes in a harmonic multi modal ensemble (Dorner et al. 2002; Flewitt R., Messer D., Kucirkova N. 2015; Kucirkova, Messer, Sheehy \& Flewitt, 2013). The opportunities for motivation and engagement with a story via touch, speech and audio are more consistent with the nature of real-life experiences (Al-Yaqout, 2011), and also allow for a more positive and receptive intervention not only for children with ASD, but for any child who needs intensive support with a certain skill (Yildirim et al., 2001). The practice entails planning, writing, scripting, obtaining feedback from peers, revising, designing storyboards, digitizing the story elements, and presenting the product to an audience (Lambert, 2007). According to Robin (2005a), "students who participate in the creation of digital stories may develop enhanced 
communications skills by learning to organize their ideas, ask questions, express opinions, and construct narratives" (p. 5).

To discover the reason for the students' eagerness to become actively engaged in the learning procedure, many theories and models have been proposed so as to explain the individuals' usage behavior towards technologies. All these technology acceptance theories have been designed to measure the degree of approval and satisfaction by the individuals against any technology or information system but from different points of view depending on the constructs or determinants which represent their structure (Momani \& Jamous, 2017). Trust in technology is an ever more imperative concept as a new mode of technologies is appearing and may become more complex and harder for some and not for others (Samaradiwakara \& Gunawardena, 2014).

The Unified Theory of Acceptance and Use of Technology (UTAUT) model established by Venkatesh et al. (2003) assesses users' intentions to use and actual use behavior of an information system (Venkatesh et al., 2003). These researchers acknowledged that the acceptance and use of technology from the consumers' perspective are affected by aspects such as performance expectancy, effort expectancy, social influence and facilitating conditions. In this way, this model has proven to be successful in a wide range of educational situations, and this is the basic reason why the UTAUT model is considered a guiding principle in examining students' behavioural intention to resort to animation and storytelling (Carlotto \& Jaques, 2016). According to specialized researchers, performance expectancy was significantly associated with students' intention to use animation and storytelling into courses (Chauhan \& Jaiswal, 2016; Lakhal \& Khechine, 2016). Additionally, by referring to the correlation coefficient values, effort expectancy would also present a significantly positive connection with students' intention to use animation and storytelling into courses (Suki, 2017; Lakhal \& Khechine, 2016; Macedo, 2017), likewise discovered that social influence constitutes a key factor for students' intention to use animation and storytelling into courses. Finally, what has equally emerged after such scientific investigations is the sound conclusion indicating that the more students are equipped with necessary knowledge and reliable resources in order to embody animation and storytelling into their courses, the more they become attuned to any technologies they make use of, in their attempt to unleash their creativity (Suki, 2017; Lakhal \& Khechine, 2016; Macedo, 2017).

To conclude, by embracing a wide range of teaching practices, including those assisted by technology, teachers meet every student's individual needs and as a result inclusive education can best respond to all students' needs.

\section{Social Stories}

In the case of students who face difficulties in generating and maintaining communication, teachers may apply more structured methods to better attract their interest and thus enhance peer interaction. A learning strategy that is claimed to serve towards these two directions is taking advantage of Social Stories (More, 2008). To render this argument even more enlightening, Social Stories are reported to constitute a method 
of interaction between a student with Autism Spectrum Disorder (ASD) and an education professional and / or a parent (Gray, 1994; Gray, 2000; Gray \& White, 2002; Gray \& Garand, 1993; Adams et al., 2004; Dianne \& Safran, 2002; Eynhout \& Carter, 2006; Smith, 2001; Smith, 2003; Gray, 2010). Such stories are approached as a means of explicitly communicating relevant information about a context, a skill, or a concept in a way totally meaningful for people belonging to the ASD. Having established an effective channel of communication between the two aforementioned parties best clarifies and more accurately explains how smoothly students of the previous categories can adjust to the new demanding linguistic environment. Therefore, any student's anxiety could possibly deescalate given that students are taught to develop a wider grasp of their social surroundings, having previously undergone a consistent training concerning how to appropriately respond to challenging educational events and stimulating social situations around them, ranging from a teacher-student interaction to peer interaction. Within this framework, Social Stories form a powerful educational tool that can encourage students to express their own ideas and emotions while acknowledging and responding other people's feeling or intentions. Needless to say, of course, that Social Stories need to be carefully designed so as to maintain the lexical load they are predetermined to convey and thus be finally considered productive and efficacious.

With reference to the position occupied by Social Stories in Special Education and Inclusive Education, scientific research so far has proven that they can assist people with ASD and / or other learning and behavioral problems in gaining far better social understanding in terms of their social surrounding and its social norms (Scattone, 2002; Toplis \& Hadwin, 2006). On the one hand, they can make them feel safe in a social context and encourage them to collaborate in group activities without fear, while, on the other hand, achieve considerably better learning goals. They, also, provide brief descriptions of a particular situation, event, or an activity, which curry along specific lexicogrammatical items in connection to what children would expect in each situation. In this sense, they pave the way for an appropriate social interaction by paying attention to other student's points of view. Social Stories typically comprise two to five sentences which are categorized as follows: a) descriptive, that is including information about the setting, participants and actions, b) directive, containing statements about the appropriate behavioral response; c) perspective, describing the feelings and reactions of other people in the targeted situations; and d) affirmative sentences, providing analogies with similar actions and responses using nonhuman subjects (Gray, 1994; Gray \& Garand, 1993).

What renders them virtually indispensable lies in the fact that such Social Stories facilitate other categories of people such as education and health professionals, parents and guardians, even therapists, to name but a few, to further understand the viewpoints that people with either ASD or communication and learning disorders have formed. Moreover, they promote a) self-care skills to these people, teaching them for example how to clean their teeth or wash their hands or get dressed; b) social skills getting accustomed for example to the notion of sharing or even how to ask for help, to say 'thank you', or to stop being impolite and last but not least academic qualifications and competences through their academic escalation. 
Another equally worth mentioning attribute of Social Stories is that they assist students in facing unexpected changes that might suddenly occur to their daily schedule or the utterly unexpected and possibly distressing events, that is a teacher's absence, a schedule alteration, or even certain frightening natural phenomena, such as thunderstorms or earthquakes. An equally significant contribution is that Social Stories are tied with the prospect of positive feedback by a young person for proper behavior patterns. This positive aspect lies mainly in the premise that social skills can ameliorate students'/children's mental health as well as their overall quality, in general. Taking into account these traits one could argue that Social Stories foster students' confidence and self esteem resulting, in this way, in socially accepted behavioral strategies, such as, decide upon, what to do when they get angry or even how to deal with their obsessions and big fears.

Social Stories may involve certain indisputable advantages related to the particular traits of people with Asperger's Syndrome Disorder which are explicitly expressed by their following features (Golan \& Baron-Cohen, 2006; Hume \& Reynolds, 2010; Moore et al., 2000):

- They represent a less threatening environment compared to an adult's or a peer's one.

- They present information in a literal, "semantic" way that can increase a person's understanding of a previously difficult or ambiguous situation.

- They are easy to implement.

- Both the presentation and the content of Social Stories can be easily conformed to meet the different needs of every single individual and especially of younger students whose needs, abilities and learning opportunities vary a lot.

- Social Stories develop sequence skills; for instance, they determine the sequential order within a cluster of activities and empower the "executive function", that is, the ability to plan and organize several activities.

- By providing concrete information about what could possibly happen in a given situation as well as some typical and fundamental behavioral guidelines, it becomes obvious that Social Stories secure every person's good quality of life and thus they reduce any feelings of intimidation and anxiety. In this case, they can apparently strengthen what is defined as self-emotion aspect.

- Developing and implementing Social Stories within classrooms can really help teachers faster realize how differently a person with ASD (Autism Spectrum Disorder) perceives a same situation.

- Social Stories permeate at all levels of formal and informal education, broadening children's cognitive spectrum and horizons.

- Social Stories exploit every need and ability associated with children's and adolescents' personality by presenting ample and explicit social information and decoding social concepts and situations. They offer useful examples of appropriate and accepted social attitudes and behaviors and direct students towards educational setting based on verbal and visual characteristics.

- They can be reiterated countless times within classrooms. 


\section{Social Stories: Chances for Inclusion}

Inclusive education as a fundamental and indispensable human right for all children overcomes all educational and social barriers as well as inequalities and eventually establishes social justice. Its main educational goal is both to include students with special educational needs in a social and school environment, to facilitate students' participation and access to the general education curriculum without any restrictions and barriers to self-evolution (Efstathiou, 2015). As demonstrated in literature, including students with disabilities in mainstream school constitutes a successful approach for ensuring that these students develop multi-facets skills as well as acquire the same educational rights as their peers (Westling \& Fox, 2009). By implementing empirically approved methods and interventions in terms of curriculum, environment and teaching methodology, teachers can reach this goal. Janney and Snell (2006) have argued that curriculum adaptations, based on linguistic simplification/structuring and the provision of multimodal information, fulfilled one of the fundamental principles of the Salamanca Statement, namely that students with and without problems should learn together. The UN Convention on the Rights of Persons with Disabilities (UNCRPD) builds on existing international human rights instruments to "promote, protect and ensure the full enjoyment of all human rights and fundamental freedoms by all persons with disabilities" (The United Nations, 2006). To enable persons with disabilities to live independently and participate fully in all aspects of life, States Parties shall take appropriate measures to make sure that persons with disabilities have access, on an equal basis with all the others, to the physical environment, to transportation, to information and communications, including information and communications technologies and systems, and to other facilities and services open or provided to the public, both in urban and in rural areas. (Article 9). On 26 ${ }^{\text {th August }} 2016$ the United Nations Committee on the Rights of Persons with Disabilities (Committee) adopted General Comment No. 4 to Article 24 (The Right to Inclusive Education). According to this, States parties should have to make appropriate provision for persons with disabilities, particularly persons on the autism spectrum, those with communication impairments and with sensory disabilities, so as them to acquire all the life, language and social skills essential for participation in education and within their communities. Learners with social communication difficulties must be consistently and robustly supported through specific adaptations to their classroom organisation, including working in pairs, peer tutoring, seating close to the teacher and suitably creating a structured and predictable learning environment.

A scientifically and empirically tested pedagogical practice with optimistic prospects as well as an educational technique ideal for both individual and group intervention that promote inclusion in both mainstream classrooms and special education environments is Social Stories. At this point, it is worth underlining that social skills have a widespread presence in diverse life environments and have also a great impact on explaining peer friendship, on understanding a structured social environment as well as on enhancing work stability (Myles, 2003; Baker \& Welkowitz, 2005). This kind of intervention does not require intensive supervision of the child's behavior or 
substantial time for implementation, making it suitable for regular education classroom settings (Chan \& O'Reilly, 2008). Besides, it is typical of Social Stories that they can be perfectly combined with other intervention strategies such as encouragement, verbal prompting, guidance and motivation.

In particular, Social Stories rely on sentences and photographs, drawings or other visual means which further highlight their content (Bock et al., 2011). Furthermore, dealing with Social Stories reduces the psycho-emotional upheavals of a child whether he/she is educationally and socially adjusted or not (Crozier \& Tincani, 2005).

Additionally, Social Stories can often be credited with reasonable patterns of behavior, reminding all the time the child with autism and other communication problems, of what he/she should omit. In the beginning, a variety of social opportunities can be offered through narration to this child within an educational and well-trained professional environment whereas in the following stage this child could be exposed to a wider range of social situations including lunch, play, school study, interests and extracurricular activities. In this framework, Social Stories provide adequate information and explanations for each event based merely on the child's cognitive and social level of individual understanding (DuCharme \& Gullotta, 2004).

To conclude, Social Stories serve as a tool for supporting inclusive education in the following ways:

- They respond to each student's level of understanding in relation with the focused needs of his or her personality on the one hand while on the other in accordance with the level of his or her emotional, cognitive and social development.

- They are an educational intervention highly recommended for students with autism and broader communication disorders, so as for them to approach and successfully analyze an event taking into serious consideration other people's point of you within their educational and wider community.

- In fact, they are part of a wider variety of interventions that also involve visual displays (images), in order for these students to further practice and strengthen their skills more independently and correctly in terms of methodology.

- It is an innovative intervention technique that takes advantage of visualized material, ranging from simple projects to digital or non-digital ones.

- Social Stories represent a challenging approach that can be introduced to students in a calm and comfortable learning environment and be also read with a positive and expressive tone.

- Students should never be made to read a story, nor should Social Stories be used as a result of inappropriate behavior.

- Teachers and students can harmoniously cooperate so as to solve any arising problem together. Sometimes a student might come across a problem or even feel frustrated. Teachers should always bear in mind that it is through social narratives that they can lay the ground for making students better understand a problem. Under these circumstances, the teacher realizes the problem faster and through various relevant ideas can help students dexterously overcome their problems and feel more comfortable even within different educational and social environments. 


\section{Digital Challenges for the Teacher: Social Stories with the Aid of Technology}

Technology has been widely embraced as an appealing form of classroom teaching. In fact, there are an increasing number of teachers who very frequently resort to technology so as to update the learning procedure for their students' benefit. There is a lot of discussion lately upon digital Social Stories, a kind of teaching Social Stories in a digital form. To put it differently, these stories are audio-visually transferred with the aid of Information and Communication Technology and can be integrated within the current educational curriculum. According to recent scientific findings, technology serves and facilitates learning, in general, while at the same time constitutes an effective means of retaining individuals' engagement in a task for longer periods of time while working on a specific learning skill (Chen \& McGrath, 2003).

According to Heward (2009), success in inclusive education requires independent work. Picture activity programs and Social Stories are exceptionally suitable for children either with or without communication, learning and school adjustment difficulties. In this frame of mind, educational videos can also become part of successful learning procedure. Overall, a set of interactive and engaging activities, except for being a powerful motivation factor, pave the way for personal evolution through self-regulation competences (Hume \& Reynolds, 2010). It is worth mentioning that specially designed computer programs can counterbalance any lack of skills, word reading, communication skills and spelling, frequently seen in cases of ASD students, through a combination of audio and visual material. This is so because children with communication, learning and behavior disorders can better respond to images, let alone digital images, rather than to complex stimuli represented by verbal or facial expressions (Reid et al., 2002).

There is also a general consensus that ICTs do play a significant role in both ensuring and enhancing learning and life-skill programs of students with Special Educational Needs. Indeed, the case study by Barry and Burlew (2004) has shown that Social Stories were implemented by a special education teacher in an attempt to teach two children with severe autism how to decide upon activity choices. According to the research results, digital Social Stories turned out to be a powerful educational tool within teachers' hands, empowering them with proper methodology directions on how to teach choice-making and play skills to children with Special Educational Needs. In this paper likewise the students were taught how to interact appropriately with the chosen materials and with the rest of the students in an Exceptional Student Education (ESE) classroom.

Jonassen and Hernandez-Serrano suggested three ways to support learning through digital stories (Jonassen \& Hernandez-Serrano, 2002). First of all, they can be used as exemplars of concepts or principles being taught by direct instruction. Secondly, they can be regarded as problem cases intended to be solved by students. Thirdly, stories can be methodologically employed as useful advice for students, being capable of helping them learn how to deal with and surpass their problems. Similarly, Gils recorded noteworthy benefits when digital storytelling becomes a necessary ingredient of education (Gils, 2005). To be more specific, this new teaching method offers much more variation as well as alternatives than traditional methods in current practice. Also, it 
personalizes learning experience and ends up explaining or practicing certain topics in a more compelling way. Additionally, it introduces real life situations into classrooms in an easy and cheaper way and, last but not least, it increasingly engages all students in the learning process. Besides, Heo's recent research indicated that digital storytelling remarkably increases students' involvement in the subject matters learning (Heo, 2009). In parallel, Robin argued that educators at all levels and nearly in all subjects can exploit digital storytelling in various ways in an attempt to enhance their students' learning (Robin, 2005b). To achieve this, they encourage students to organize and express their ideas and knowledge in an individual and meaningful way, adopting this current digital storytelling technique. Likewise, in Daigle and Sulentic-Dowell's (2010) study focused on the use of digital storytelling as an intervention to improve the academic performance and social interactions of a sixth-grade-student with high-functioning autism, positive and hopeful findings were reported.

Digital storytelling is another way of representing individual narratives. Its origins go back to the work of Joe Lambert and Dana Atchley in the USA in the 1980s (Parsons et al., 2015). The main elements of the digital story's structure and content, are explained, explored and illustrated in more detail in the latest version of the Digital Storytelling Cookbook (Lambert, 2014) along with a specific process for developing stories through workshops and particular techniques. According to Lambert (2013) Digital stories have been widely used in community activism, public health care, social services, international development, public broadcasting and in business. However, it was not until recently that this method took place in educational contexts (Robin, 2008), having actually two main forms: (1) as constructivist teaching and learning activities specially designed for students in order to enhance digital media skills as well as topic-specific learning outcomes through achieving deeper and more substantial engagement with the course target (Ohler, 2013) and (2) as an approach by which teachers can discuss topics by making " ... abstract or conceptual content more understandable" (Robin, 2008, p. 224).

Nowadays, there is a great variety of Digital Stories software such as PhotoStory3, Animoto, ComicLife, StoryBird, Digital Vaults, Voice Thread and Glogster as well as Kerpoof that are capable of producing a story with same images and a text through a technological mediation. ICT experts argue that computer users can dexterously place images in a row so as to create their own story, since there is no predetermined correct or wrong order (Chatzara et al., 2014). In a different context, Karimi and Lim (2010) developed a 3D digital narrative that integrates education, entertainment and social commitment in order to measure children's time engagements and facial expressions during storytelling sessions.

Tsai et al. (2007) argued that if we can learn social norms and expectations from others in the real world, then it seems likely that we might also do the same while observing fictional characters in a story world. According to Kulla-Abbott and Polman (2008), a digital storytelling program facilitates students in improving their writing skills because they are asked to come up with and organize a new sequence of original images relevant to their own ideas. Lindsey-Glenn and Gentry (2008) reported promising results following the use of Digital Stories to improve vocabulary skills of students with ASD. 
Another equally beneficial aspect of digital stories is their contribution to improving the learning process of children with autism as proposed in researchers who have found out that the digital stories fostered reflection and critique of the teaching and learning opportunities for pupils who were afforded through the use of the new technologyenhanced learning environments (Parsons et al., 2015). Children with autistic attributes created stories by dragging and dropping the hand-drawn pictures into the story's timeline, and also by drawing pictures of their own. The stories were saved to the story library. The children then could print out their stories and put together their own story books. The study was conducted as action research premised on the children's active roles as participants and developers, the empowerment of children's strengths and creativity, and the modifiability and transformability of technology solutions. The learning environment included storytelling and game playing. According to the results, the strength-based approach and versatile technology solutions engaged children with autistic features as active participants and creative actors.

Besides, researchers have concluded that Digital Stories can render students more engaged in school tasks, oral and writing, and turn to be more creative, because they get exposed to different ways of expressing their personal ideas (Kulla- Abott \& Polman, 2008; Pennington, Collins, Stenhoff, Turner, \& Gunselman, 2014). In particular, Jones and Love (2012) underlined that digital-based Social Stories effectively engage students in their technologically-assisted activities, while helping them monitor and control their behavior as well as expand their attention span during their computer work.

In conclusion, Social Stories constitute a practical approach to both teamwork and individual work including children with ASD, but also offer some guidelines practical guidance for teachers, education, social welfare and health professionals and parents. All of them support the whole learning procedure; that is, not only school and cultural inclusion but also social inclusion of students with Special Educational Needs and particularly those having communication and adaptation problems in their general educational community as well as in various social groups (Dettmer et al., 2000).

In Greece, there are some enlightening example of integrated digital material (Riga, Ioannidi \& Papayiannis, 2020). One of them is the Teacher's Guide for the development of social and emotional skills, Life Skills and Autonomous Living for Students with Social Disabilities prepared by the Institute of Educational Policy (http://prosvasimo.iep.edu.gr/el/koinonikesistories).

In addition, another noteworthy case is presenting Social Stories and Digital Stories (e-stories) in connection with current issues social reality due to the COVID-19. The ongoing Greek experience refers to relevant examples:

1) The Institute of Educational Policy provides an illustrated story in "How to protect ourselves from the corona virus" (Gelastopoulou \& Papamichalopoulou, n.d.) with emphasis on the quality of life named "Wellbeing".

2) The Laboratory of School Psychology of the National and Kapodistrian University of Athens offers digital material with useful instructions focusing onto a transition to the digital classroom. This material is combined with activities to strengthen social and emotional bonds in emergencies, with reference points to students, 
teachers and school educators, parents and families, as well as school psychologists (http://www.centerschoolpsych.psych.uoa.gr/index.php/2020-0327-17-58-58).

3) And a translated digital story (Daemicke, n.d.), illustrated with an informative character who explains the current virus situation in simple terminology in order to motivate children to deal with every aspect of the virus reality more efficaciously.

\section{Conclusion}

This paper argues that social constructivist learning theory can offer an explanation for the mechanisms behind Social Stories and how they can promote interaction and collaboration among for individuals on the autistic spectrum. Meanwhile, this paper intends to bring about some very meaningful and encouraging outcomes for children with autism or other kinds of Special Educational Needs. This foundational knowledge will certainly enhance teachers', parents' and other school practitioners' intrigued to integrate learning methods build upon Social Stories in their teaching methodology with a view to offering targeted and effective instructional opportunities to their students with Special Educational Needs.

From the aforementioned scientific data what clearly arises is the fact that teachers should be able to engage their students in the learning process by providing them with diversified methods of knowledge conquest as a means of motivating all of their students regardless of their physical, mental and emotional condition (Soulis, 2002). Similarly, since the majority of students with learning disabilities face social communication problems, it can be argued that such teaching interventions can be applied to a wider population of students working in more inclusive settings.

Establishing new social ties at mainstream education requires students to have adequate social skills and confidence to come in contact with the others. From the aforementioned scientific data what clearly arises is the fact that teachers should be able to engage their students in the learning process by providing them with diversified methods of knowledge conquest as a means of motivating all of their students regardless of their physical, mental and emotional condition (Soulis, 2002). Similarly, since the majority of students with learning disabilities face social communication problems, it can be argued that such teaching interventions can be applied to a wider population of students working in more inclusive settings.

To conclude, it is very crucial for students either with or without disabilities to become more competent in various social interactions at all stages of physiological and communicative development. Therefore, communicative isolation, a common characteristic of students with special education needs, makes it hard for them to develop adequate communicative and social skills (Müller et al., 2008). 


\section{Future Implications}

Referring to Koegel (2000), although researchers have made great progress in both assessing and mediating in the communication field, yet there are still many pivotal research gaps. For instance, it is of utmost importance that further investigation take place in relation to how effective Social Stories can be for adults and children displaying a lower level in their cognitive and functional operations (Mavropoulou, 2011). Future research also has to concentrate onto key "crucial areas," such as child self-initiatives (Koegel et al., 1999) because they are likely to trigger off radical and widespread changes in behavior, let alone have a positive impact on other areas that have moved beyond research space, namely, memory and attention span (Matson et al., 1996).

Finally, it is expected that using digital Social Stories is a well promising method for making the learning procedure more alluring and challenging for all students. It is also under investigation whether students learning acquisition as well as its ensuing application will be raised to a larger extend when engaged in individual compared to cooperative activities. Future research thus needs focusing on testing how fruitful Social Stories can be when applied to a larger number of students with AS working in different communication settings. However, our focus should not only be restricted in lifelong social skills but in other skills too, namely safety and self-care dexterities as well as in different school subjects such as Mathematics and History.

To sum up, there is undoubtedly a need for specialized, practical and intensive educational interventions with the aid of appropriate digital material given that teachers face several challenges while teaching. It is true that ICT elements can bring about radical changes in the way modern pedagogical approach and school inclusion process work in cases of students with Special Educational Needs.

\section{Conflict of Interest Statement}

The authors declare no conflicts of interests.

\section{About the Authors}

Dr. Riga Asimina is a Special Education Teacher in Secondary and Higher Education. She holds a doctorate in Special Education from the University of Thessaly in Greece. She has taught Special Education, Language Processing and Educational interventions in oral and written problems, at the University of Patras, at Hellenic Open University and at University of Nicosia, Cyprus. Dr Riga is currently a Greek Language Teacher in special education structures and Collaborating Teaching Staff in the Joint Postgraduate Program of Education Science Studies: Special Education and Education of Students with Oral and Written Problems, University of Thessaly and Hellenic Open University. Her research focuses primarily on Language Teaching in students with Special Education Needs and on the use of Information and Communication Technologies (ICT) in Special Needs Education.

Dr. Vasiliki Ioannidi is an Adjunct Faculty of School of Education at the University of Nicosia and is Researcher-Author/Collaborating Teaching Staff at the National and 
Kapodistrian University of Athens (NKUA) on the subjects "Pedagogies, Special \& Inclusive Education, Social Stories as Intervention in Special Education and Digital Education". She is a member of "Intelligent Deep Analysis", a think tank of the NKUA. Also, she is a member of the ÖGKJP-Sektion Klinische Pädagogik and she teaches in the Program of Pedagogy at the Hellenic Open University. She completed her B.A. in Philology and Ph.D. in Pedagogy in the School of Philosophy at the NKUA, with a specialization "Special Education" (Greek State Scholarship Foundation) and certification in Special Education Programs, Neurosciences \& Education, Adult Education, Adult Educators Training and Open \& Distance Learning. She has extensive research and teaching experience (undergraduate \& postgraduate level and e-learning programs) in Higher Education. She has published books and authored journal articles, book chapters, e-books and conference papers. Her writings have been published in three languages (Greek, English, German). Among her current research interests are the use of innovative and best practices in Inclusive Pedagogy and Special \& Inclusive Education with an emphasis on interdisciplinary collaboration and the enhancement of Digital Education through Teachers' education activities.

Nikolaos Papayiannis has a BA in English Language and Literature from Aristotle University, Greece and a MA in American Literature and Culture of the same Department. He has twenty-two years of experience in EFL and finally, he has taken active part in educational scientific article publications.

\section{References}

Adams L, Gouvousis A, VanLue M, Waldron C, 2004. Social story intervention: Improving communication skills in a child with an autism spectrum disorder. Focus on Autism E Other Developmental Disabilities, 19 (2), pp. 87-94.

Alameen G, 2011. Learner Digital Stories in A Web 2.0 Age. TESOL Journal 2 (3), pp. 355369.

Al-Yaqout G, 2011. From slate to slate: what does the future hold for the picturebook Series? New Review of Children's Literature and Librarianship, 17.1, pp. 57-77.

Baker L J, Welkowitz, L A, (ed.) 2005. Asperger's Syndrome. Intervening in Schools, Clinics and Communities. New York, London: Routledge.

Bandura A, 2001. Social cognitive theory of mass communication. Media Psychology, 3 (3), pp. 265-299. doi:10.1207/ S1532785XMEP0303_03

Barry L M, Burlew S B 2004. Using Social Stories to Teach Choice and Play Skills to Children with Autism. Focus on Autism and Other Developmental Disabilities, 19 (1), pp. 45-51. Available: https://doi.org/10.1177/10883576040190010601

Bawazir R, Jones P, 2017. A Theoretical Framework on Using Social Stories with the Creative Arts for Individuals on the Autistic Spectrum, World Academy of Science, Engineering and Technology, Open Science Index 129. International Journal of Medical and Health Sciences, 11 (9), pp. 533-541. 
Bock M, Rogers M F, Myles B S, 2011. Using Social Stories and Comic Strip Conversations to Interpret Social Situations for an Adolescent with Asperger Syndrome. Intervention in School and Clinic, 36 (5), pp. 310-313. Available: https://doi.org/10.1177/105345120103600510

Booth T, 1996. A perspective on inclusion from England. Cambridge Journal of Education, 26 (1), pp. 87-99.

Carlotto T, Jaques P A, 2016. The effects of animated pedagogical agents in an English-as a-foreign language learning environment. International Journal of Human-Computer Studies, 95, pp. 15- 26.

Chan J M, O'Reilly M F, (2008). A Social Stories intervention package for students with autism in inclusive classroom settings. Journal of applied behavior analysis, 41 (3), pp. 405-409. https://doi.org/10.1901/jaba.2008.41-405

Chatzara K, Karagiannidis Ch, Mavropoulou S, Stamatis D, 2014. Digital Storytelling for Children with Autism: Software Development and Pilot Application. In: Politis P, I Karasavvidis I, Karagiannidis C, (Eds.), Research on e-learning and ICT in education: Technological, pedagogical and instructional perspectives, pp. 287-300. United States of America: Springer.

Chauhan S, Jaiswal M, 2016. Determinants of acceptance of ERP software training in business schools: Empirical investigation using UTAUT model. The International Journal of Management Education, 14, pp. 248-262.

Chen P, McGrath D, 2003. Moments of Joy. Journal of Research on Technology in Education, 35:3, pp. 402-422. DOI: 10.1080/15391523.2003.10782393

Crozier S, Tincani M J, 2005.Using a Modified Social Story to Decrease Disruptive Behavior of a Child with Autism. Focus on Autism and Other Developmental Disabilities, 20 (3), pp. 150-157. https://doi.org/10.1177/10883576050200030301

Daigle B, Sulentic Dowell M-M, 2010. Can digital storytelling improve outcomes for students with autism? Georgia Journal of Reading, 33 (1), pp. 25-34.

Daemicke S M, n.d. Be a Coronavirus Fighter. Translation: N. Zampakh. Available: https://yeehoopress.com/coronavirus-picturebookgreek/?fbclid=IwAR19HTPDCI0D13mMp5oXtleEzEQoFdZcPouGGc2AGRfE]kpE5etwqMDO4Q [Accessed 18/4/2020] [in Greek].

Dettmer S, Simpson R, Myles B, Ganz J, 2000. The use of visual supports to facilitate transitions of students with autism, Focus on Autism and Other Developmental Disabilities, 15, pp. 163-169.

Dianne M, Safran G, 2002. Cooperative learning and social stories: Effective social skills strategies for reading teachers. Reading $\mathcal{E}$ Writing Quarterly, 18:1, pp. 87-91. DOI: $10.1080 / 105735602753386351$

Dorner R, Grimm P, Abawi D, 2002. Synergies between interactive training simulations and digital storytelling: a component-based framework. Computers $\mathcal{E}$ Graphics, 26, pp. 45-55.

DuCharme R Nw, Gullotta T P, 2004. Asperger Syndrome. A Guide for Professionals and Families. Springer Science + Business Media LLC. 
Efstathiou M, 2015. Educational Policies and Curricula for people with disabilities. Ioannina: Miller.

Efstathiou M, 2015. Diagnosis, Assessment, and the Education of People with Disabilities in Greece and the Struggle for inclusive education. Thessaloniki: Graphima.

Eynhout G, Carter M, 2006. Social Stories for Children with Disabilities, Journal of Autism and Developmental Disorders, 36, pp. 445-469. doi:10.1007/s10803-006-0086-1

Evans J, Lunt I, 2002. Inclusive education: are there limits? European Journal of Special Needs Education, 17:1, pp. 1-14. DOI: $\underline{10.1080 / 08856250110098980}$

Flewitt R, Messer D, Kucirkova N, 2015. New directions for early literacy in a digital age: The iPad. Journal of Early Childhood Literacy, 15(3), pp. 289-310. doi: $10.1177 / 1468798414533560$

Gelastopoulou M, Papamichalopoulou E, n.d. How are we protecting from coronavirus. Athens: Institute of Educational Policy, Ministry of Education and Religious Affairs. Available:

http://prosvasimo.iep.edu.gr/koronoios/Koronoios\%20KI\%20Book.pdf?fbclid=IwAR35f 5mEp5UCH4C37SWR2MW-pe0VydQfx65p-9U30syfujtPlAQ-5uuCq U [Accessed 18/4/2020] [in Greek].

Gils F, 2005. Potential applications of digital storytelling in education. In: 3rd Twente Student Conference on IT, University of Twente, Faculty of Electrical Engineering, Mathematics and Computer Science, Enschede, February 17-18.

Golan O, Baron-Cohen S, 2006. Systemizing empathy: Teaching adults with Asperger syn-drome or high-functioning autism to recognize complex emotions using interactive multimedia. Development and Psychopathology, 18, pp. 591-617.

Gray C, 1994. Making sense out of the world: Social stories, comic strip conversations, and related instructional techniques. Kansas City, MO: Midwest Educational Leadership Conference on Autism.

Gray C, 2000. The New Social Story Book. Arlington: Future Horizons, Inc. Available: https://books.google.gr/books?hl=en\&lr=\&id=6ysB9NkTSNYC\&oi=fnd\&pg=PP19 $\& \mathrm{dq}=$ SOCIAL+STORY\&ots=AeWrJCc4qX\&sig=tK9FIHPPGvVAIfWHIWLmTK8k k14\&redir esc $=\mathrm{y} \# \mathrm{v}=$ onepage $\& \mathrm{q}=S O C I A L \% 20 S T O R Y \& \mathrm{f}=$ false $\quad$ [Accessed $18 / 4 / 2020]$.

Gray C, 2010. Social Stories. Definition, Criteria $\mathcal{E}$ Sample Stories. Available: http://blogs.4j.lane.edu/communityaccess/files/2013/05/Social-Story-Criteria.pdf [Accessed 18/4/2020].

Gray C A, Garand J D, 1993. Social stories: Improving responses of students with autism with accurate social information. Focus on Autistic Behavior, 8 (1), pp. 1-10.

Gray C, White A L 2002. My Social Stories Book. London and Philadelphia: Jessica Kingsley Publishers. Available:

https://books.google.gr/books?hl=en\&lr=\&id=jyYQBQAAQBAJ\&oi=fnd\&pg=PA2\&dq=S ocial+stories\&ots=GHbILet4-

L\&sig=FcMRahL5PZZwjt1AoYRuBfkeGL4\&redir esc=y\#v=onepage\& $\mathrm{q}=\mathrm{social} \% 2$ 0stories\&f=false [Accessed 18/4/2020]. 
Gregori-Signes C, 2014. Digital storytelling and multimodal literacy in education. Porta Linguarum, 22, pp. 237-250.

Heo M, 2009. Digital storytelling: An empirical study of the impact of digital storytelling on pre-service teachers' self efficacy and dispositions towards educational technology. Journal of Educational Multimedia and Hypermedia, 18 (4), pp. 405-428.

Heward W L, 2009. Exceptional children. An introduction to Special Education. N. J.: Pearson Education.

Hume K, Reynolds B, 2010. Implementing work systems across the school day: Increasing engagement in students with autism spectrum disorders. Preventing School Failure, 54, pp. 228-237.

Ioannidi V, 2020. A first educational approach to connecting knowledge and skills. European Journal of Literature, Language and Linguistics Studies, 3, 4, pp. 62-67. Available: https://oapub.org/lit/index.php/EJLLL/article/view/160

Janney R, Snell M E, 2006. Social relationships and peer support (2nd ed.). Baltimore, Md.: Paul H. Brookes Publisher.

Jonassen D H, Hernandez-Serrano J, 2002. Case-based reasoning and instructional design using stories to support problem solving. Educational Technology Research and Development, 50 (2), pp. 65-77.

Jones J, Love S, 2012. Living social: How to use social stories as behavior intervention. $i$ Manager's Journal on School Educational Technology, 8 (3), pp. 9.

Karimi A, Lim Y P, 2010. Children, engagement and enjoyment in digital narrative. ASCILITE 2010 - The Australasian Society for Computers in Learning in Tertiary Education, (2001), pp. 475-483.

Kennedy C K, Bhagavatula L, Bedford S, Bennett Jr R, Dorleans S, Halden J, Hoffmann P, Morris J, Perez M, Porcell C, 2019. Social Stories for Targeting Behaviors and Developing Empathy in Adolescents with Autism Spectrum Disorder: An Innovative Technology-Assisted Intervention. In: Scientific Concepts Behind Happiness, Kindness, and Empathy in Contemporary Society, pp. 237-255. IGI Global, Web. 3 May. 2020. doi:10.4018/978-1-5225-5918-4.ch012

Koegel L K, 2000. Interventions to Facilitate Communication in Autism. J Autism Dev Disord 30, pp. 383-391, Available: https://doi.org/10.1023/A:1005539220932

Koegel L K, Koegel R L, Shoshan Y, McNerney E, 1999. Pivotal Response Intervention II: Preliminary long-term outcome data. Journal of the Association for Persons with Severe Handicaps, 24, pp. 186-198.

Kucirkova N, Messer D, Sheehy K and Flewitt R S, 2013. Sharing personalised stories on iPads: A close look at one parent-child interaction. Literacy 47(3): pp. 115-122.

Kulla-Abbott T, Polman J, 2008. Engaging student voice and fulfilling curriculum goals with digital stories. Technology, Humanities, Education \& Narrative, 5, pp. 38-60.

Lakhal S, Khechine H, 2016. Student intention to use desktop web-conferencing according to course delivery modes in higher education. The International Journal of Management Education, 14, pp. 146-160. 
"Laboratoty of School Psychology". National and Kapodistrian University of Athens. Available: http://www.centerschoolpsych.psych.uoa.gr/index.php/2020-03-27-1758-58 Accessed 18/4/2020 [in Greek]

Lambert J, 2007. Digital storytelling cookbook. Retrieved from https://wrd.as.uky.edu/sites/default/files/cookbook.pdf

Lambert J, 2010. The Digital Storytelling Cookbook. Berkeley. CA: Digital Diner Press/Center for Digital Storytelling. [Accessed June 13, 2014]. http://storycenter.org/books/. [Google Scholar]

Lambert J, 2013. Digital Storytelling: Capturing Lives, Creating Community, 4th ed. Abingdon: Routledge. [Crossref], [Google Scholar]

Leach D, Duffy M L, 2009. Supporting Students with Autism Spectrum Disorders in Inclusive Settings. Intervention in School and Clinic, 45 (1), pp. 31-37. Available: https://doi.org/10.1177/1053451209338395

Lee L, 2014. Digital news stories: Building Language Learners' Content Knowledge and Speaking Skills. Foreign Language Annals, 47 (2) pp. 338-356.

Lindsey-Glenn P F, Gentry J E, 2008. Improving vocabulary skills through assistive technology: Rick's story. TEACHING Exceptional Children Plus, 5 (2) Article 1. Retrieved November 19, 2013, from http://escholarship.bc.edu/education/tecplus/vol5/iss2/art1

Macedo I M, 2017. Predicting the acceptance and use of information and communication technology by older adults: An empirical examination of the revised UTAUT2. Computers in Human Behavior, 75, pp. 935-948.

McLeod S A, 2018, August 05). Lev Vygotsky. Simply Psychology. https://www.simplypsychology.org/vygotsky.html

Matson J L, Benavidez D A, Compton L S, Paclawskyj T, Baglio C S, 1996. Behavioral treatment of autistic persons: A review of research from 1980 to the present. Research in Developmental Disabilities, 17, pp. 433-465.

Mavropoulou S, 2011. Effective educational approaches and teaching strategies for children in the autism spectrum. In: Padeliadou S, Argyropoulos B, (eds), Special Education: From research to teaching practice. Athens: Pedio.

Meadows D, 2003. Digital storytelling: Research-based practice in new media. Visual Communication, 2 (2), pp. 189-193.

Mittler P, 2000. Working Towards Inclusive Education: social contexts. London: David Fulton. Momani Alaa M, Jamous M, 2017. The Evolution of Technology Acceptance Theories. International Journal of Contemporary Computer Research (IJCCR), 1 (1), pp. 51-58. Available: SSRN: $\underline{\text { https://ssrn.com/abstract=2971454 }}$

More C, 2008. Digital Stories Targeting Social Skills for Children with Disabilities: Multidimensional Learning. Intervention in School and Clinic, 43 (3), pp. 168-177. Available: https://doi.org/10.1177/1053451207312919

Moore D J, McGrath P, Thorpe J, 2000. Computer aided learning for people with autism - a framework for research and development. Innovations in Education and Training International, 37, pp. 218-228. 
Myles B S, 2003. Social Skills Instruction for Children with Asperger Syndrome. In: R.W. DuCharme, T.P. Gullotta (eds), Asperger Syndrome. Issues in Children's and Families' Lives, vol 3. Boston, MA: Springer.

Müller E, Schuler A, Yates G B, 2008. Social challenges and supports from the perspective of individuals with Asperger syndrome and other autism spectrum disabilities. Autism, 12 (2), pp. 173-190. Available: https://doi.org/10.1177/1362361307086664

Nishioka H, 2016. Analysing Language Development. In: A Collaborative Digital Storytelling Project: Sociocultural Perspectives System, 62, pp. 39-52.

O'Byrne W I., Stone R, White M, 2018. Digital Storytelling in Early Childhood: Student Illustrations Shaping Social Interactions. Frontiers in psychology, 9, 1800. https://doi.org/10.3389/fpsyg.2018.01800

Ohler J B, 2013. Digital Storytelling in the Classroom: New Media Pathways to Literacy, Learning, and Creativity, 2nd ed. London: Sage. [Google Scholar]

Pennington R, Collins B, Stenhoff D, Turner K, Gunselman K, 2014. Using Simultaneous Prompting and Computer-Assisted Instruction to Teach Narrative Writing Skills to Students with Autism. Education and Training in Autism and Developmental Disabilities, 49(3), 396-414. Retrieved May 15, 2021, from http://www.jstor.org/stable/23881260

Park E J, Seo J H, 2009. Applying digital storytelling technique to website navigation for improving emotional user experience. Proceeding of the International Association of Societies of Design Research, pp. 4125-4128. Seoul, Korea.

Parsons S, Guldberg K, Porayska-Pomsta K, Lee R, 2015. Digital stories as a method for evidence-based practice and knowledge co-creation in technology enhanced learning for children with autism, Int. J. Res. Meth. Educ. 38 (3), pp. 247-271. Available: https://doi.org/10.1080/1743727X.2015.1019852

Reid M, Burn A, Parker D, 2002. Evaluation report of the Becta Digital Video pilot project. Retrieved September 12, 2020, from: https://www.researchgate.net/publication/237598160 Evaluation Report of the Becta Digital Video Pilot Project

Riga, A., Ioannidi, V., \& Papayiannis, N. (2020). Autism Spectrum Disorder and Social Stories Purpose and Utility. Asian Journal of Education and Social Studies, 12(4), 1926. https://doi.org/10.9734/ajess/2020/v12i430317

Riga A, Andreou G, 2018. Students with ADHD: The impact of Information and Communication Technologies and their mothers' occupational status on writing skills. Global Journal of Special Education and Services, 6 (2), pp. 126-135.

Robin B, 2005a. Educational uses of digital storytelling. Main directory for the educational uses of digital storytelling. Instructional technology Program. University of Huston. Retrieved from: Journal of Education and Practice, www.iiste.org ISSN 2222-1735 (Paper) ISSN 2222-288X (Online) Vol.6, No.9, p. 129. Available: http://faculty.coe.uh.edu/brobin/homepage/Educational-Uses-DS.pdf

Robin B, 2005b. Educational uses of digital storytelling. Main directory for the educational uses of digital storytelling. Instructional technology Program. University of Huston. 
Available: http://www.coe.uh.edu/digitalstorytelling/default.htm. Retrieved 12 February 2019

Robin B, 2006. The educational uses of digital storytelling. In: C. Crawford et al. (Eds.), Proceedings of Society for Information Technology and Teacher Education International Conference, pp. 709-716. Chesapeake, VA: AACE.

Robin B R, 2008. Digital Storytelling: A Powerful Technology Tool for the 21st Century Classroom. Theory into Practice, 47 (3), pp. 220-228. doi: 10.1080/00405840802153916

Robin B R, 2016. The Power of Digital Storytelling to Support Teaching and Learning. Digital Education Review, Number 30. Available: http:/greav.ub.edu/der/

Sadik A, 2008. Digital storytelling: A meaningful technology-integrated approach for engaged students learning. Educational Technology Research and Development, 56 (4), pp. 487-506.

Samaradiwakara G D M N, Gunawardena C G, 2014. Comparison of Existing Technology Acceptance Theories and Models to Suggest a Well Improved Theory/Model. Int. Tech. Sci. J., 1 (1), pp. 21-36.

Sansosti F J, Powell-Smith K A, 2008. Using Computer-Presented Social Stories and Video Models to Increase the Social Communication Skills of Children with HighFunctioning Autism Spectrum Disorders. Journal of Positive Behavior Interventions, 10 (3), pp. 162-178. Available: https://doi.org/10.1177/1098300708316259

Scattone D, 2002. Increasing appropriate social interactions of children with autistic spectrum disorders using Social Stories (Doctoral dissertation). University of Southern Mississippi, Mississippi.

Smeda N, Dakich E, Sharda N, 2012. Digital Storytelling with Web 2.0 Tools for Collaborative Learning. In: Okada A, Connolly T, Scott P J, (eds), Collaborative Learning 2.0: Open Educational Resources, pp. 145-163. IGI Global, Hershey, Pennsylvania.

Smeda N, Dakich E, Sharda N, 2014. The effectiveness of digital storytelling in the classrooms: a comprehensive study. Smart Learn. Environ. 1, 6. Available: https://doi.org/10.1186/s40561-014-0006-3

Smith C, 2001. Using social stories with autistic spectrum disorders: an evaluation. Good Autism Practice, 2 (1), pp. 16-25.

Smith C, 2003. Writing \& Developing Social Stories. Practical interventions in Autism. London, New York: Routledge, Taylor \& Francis Group.

"Social Stories". Athens: Institute of Educational Policy. Available: http://prosvasimo.iep.edu.gr/el/koinonikesistories [Accessed 8/5/2020] [in Greek].

"Social Stories". Centre for Autism. Best Practice Resource. Middletown. Available at: http://best-practice.middletownautism.com/approaches-of-intervention/socialstories/ [Accessed 7/5/2020].

Soulis S, 2002. Pedagogy of Integration (Volume A), Athens: Typothito. [in Greek].

Standley M, 2003. Digital storytelling using new technology and the power of stories to help our students learn and teach. Cable in the Classroom, http://www.ciconline.org/home. 
Suki N M, 2017. Students' Intention to Use Animation And Storytelling: Using The Utaut Model AIMC 2017. Asia International Multidisciplinary Conference. DOI: $10.15405 /$ epsbs.2018.05.5

The United Nations. (2006). Convention on the Rights of Persons with Disabilities. Treaty Series, 2515, 3.

Toplis R, Hadwin A J, 2006. Using Social Stories to change problematic lunchtime behavior in school. Educational Psychology in Practice, 22, pp. 53-67.

Tsai J L, Louie J Y, Chen E E, Uchida Y, 2007. Learning what feelings to desire: Socialization of ideal affect through children's storybooks. Personality and Social Psychology Bulletin, 33 (1), pp. 17-30. doi:10.1177/0146167206292749

Tsou W, Wang W, Tzeng Y, 2006. Applying A Multimedia Storytelling Website in Foreign Language Learning. Computers $\mathcal{E}$ Education, 47, pp. 17-28.

UN Committee on the Rights of Persons with Disabilities (CRPD), General comment No. 4 (2016), Article 24: Right to inclusive education, 2 September 2016, CRPD/C/GC/4, available at: https://www.refworld.org/docid/57c977e34.html [accessed 15 May 2021]

Yildirim Z, Ozden M Y, Aksu M, 2001. Comparison of hypermedia learning and traditional instruction on knowledge acquisition and retention. The Journal of Educational Research, 94, pp. 207-214.

Yuksel P, Robin B, McNeil S, 2011. Educational uses of digital storytelling around the world. In: M. Koehler \& P. Mishra (Eds.), Proceedings of Society for Information Technology \& Teacher Education International Conference, pp. 1264-1271. Chesapeake, VA: AACE.

Udvari-Solner A, 2012. Collaborative Learning. In: Seel N.M. (eds) Encyclopedia of the Sciences of Learning. Boston, MA: Springer.

Venkatesh V, Morris M G, Davis G B, Davis F D, 2003. User acceptance of information technology: Toward a unified view. MIS Quarterly, 27, (3), pp. 425-478.

Verdugo D R, Belmonte I A, 2007. Using Digital Stories to Improve Listening Comprehension with Spanish Young Learners of English. Language Learning $\mathcal{E}$ Technology 11(1), pp. 87-101.

Westling D, Fox L, 2009. Teaching students with severe disabilities (4th ed.). Upper Saddle River, New Jersey: Merrill Prentice Hall. 

be applied to their work. Under the terms of this license, no permission is required from the author(s) or publisher for members of the community to copy, distribute, transmit or adapt the article content, providing a proper, prominent and unambiguous attribution to the authors in a manner that makes clear that the materials are being reused under permission of a Creative Commons License. Views, opinions and conclusions expressed in this research article are views, opinions and conclusions of the author(s). Open Access Publishing Group and European Journal of Special Education Research shal not be responsible or answerable for any loss, damage or liability caused in relation to/arising out of conflict of interests, copyright violations and inappropriate or inaccurate use of any kind content related or integrated on the research work. All the published works are meeting the Open Access Publishing requirements and can be freely accessed, shared, modified, distributed and used in educational, commercial and non-commercial purposes under a Creative Commons Attribution 4.0 International License (CC BY 4.0). 